\title{
Fortification of Modified Cassava Flour through Application of Fermented Food Containing Poly-Glutamic Acid
}

\author{
Joko Sulistyo Soetikno*, Joanna Ho Swee Ling and Yu Shin Ying \\ Faculty of Food Science and Nutrition, University Malaysia Sabah, Jalan UMS 88400, \\ Kota Kinabalu, Sabah Malaysia
}

*Corresponding author: Joko Sulistyo, Faculty of Food Science and Nutrition, University Malaysia Sabah, Jalan UMS 88400, Kota Kinabalu, Sabah Malaysia, Tel +60-109772815; E-mail: jokosulistyo@ums.edu.my

\section{Abstract}

Present study was designed to investigate properties of fortified cassava flour produced from co-processing of modified cassava flour with poly-glutamic acid (PGA) derived from protein of beans that had been fermented by Aspergillus oryzae and Bacillus natto. Proximate analysis, cyanide content, swelling power, solubility and viscosity of modified cassava flour (MCF) which was fortified with PGA was found to indicate improvements as compared to native cassava flour (NCF). The protein content of fortified cassava flour (FCF) showed significantly increased $\left(5.29 \pm 0.01^{\mathrm{b}}\right.$ to $13.98 \pm 0.79 \mathrm{~d}$ and $4.72 \pm 0.06^{\mathrm{c}}$ to $12 \pm 006^{\mathrm{e}}$ using PGA derived from A. oryzae and B. natto, respectively) as compared to the NCF (1.08 $\pm 0.02^{\mathrm{a}}$ and $\left.1.06 \pm 0.11^{\mathrm{b}}\right)$ and crude fiber of FCF showed significantly increased as well $\left(1.55 \pm 0.01^{\mathrm{c}}\right.$ to $3.31 \pm 0.04 \mathrm{e}$ and $2.31 \pm 0.11^{\mathrm{c}}$ to $3.08 \pm 010^{\mathrm{e}}$ as compared to crude fiber of NCF $\left(1.25 \pm 0.57^{\mathrm{b}}\right.$ and $\left.1.58 \pm 0.05^{\mathrm{a}}\right)$. Swelling power of $\mathrm{NCF}\left(20.62 \pm 4.04^{\mathrm{b}}\right.$ and $\left.21.75 \pm 0.12^{\mathrm{e}}\right)$ was significantly decreased as compared to FCF $\left(11.59 \pm 0.09^{\mathrm{a}}\right.$ to $11.02 \pm 0.20^{\mathrm{a}}$ and $14.34 \pm 0.19^{\mathrm{c}}$ to $9.48 \pm 0.11^{\mathrm{a}}$ using PGA derived from A. oryzae and B. natto, respectively), meanwhile solubility of NCF $\left(11.26 \pm 0.11^{\mathrm{a}}\right.$ and $\left.11.57 \pm 0.25^{\mathrm{a}}\right)$ was significantly increased as compared to FCF $\left(16.42 \pm 0.30^{c}\right.$ to $23.09 \pm 0.18^{\mathrm{e}}$ and $16.68 \pm 0.17 \mathrm{c}$ to $23.48 \pm 0.20^{\mathrm{e}}$. Observation by scaning electron microscope (SEM) indicated that starch granules of MCF and FCF were depolymerized by enzymatic hydrolysis lead to cause change and degrade exterior surface of the granules within corrosion via pores of small granules.

Keywords: Modified cassafa flour; Fortification; Polyglutamic acid; Physicochemical properties

Abbreviations: PGA: poly-glutamic acid; MCF: modified cassava flour; NCF: native cassava flour; FCF: fortified cassava flour

\section{Introduction}

Cassava (Manihot esculenta crantz) is one of the leading food plants in the world; it ranks fourth among staple crops with a global production of about 160 million tons per year [1]. Cassava is often castigated as an "inferior food crop" and "poor people crop" [2]. These labels on cassava were due to some limitations of the crop including low quality and quantity of protein Cooke and Coursey [3] and have major drawbacks of poor starch and protein digestibilities that undermine its nutritional 


\section{Food Science and Nutrition Technology}

value and thus it has been underutilized compared to wheat [4].

Modification of native cassava starches using various chemical reagents makes significant variation in the structural, physicochemical, thermal and rheological properties of starch. Demiate and Cereda [5] proposed a chemical modification of cassava starch that resulted in high degree of expansion of the product. Modified starch is more resistant to acid, heat and shearing than is native starch [6,7] and therefore modified starch is suitable for canned food and other applications [8]. In recent years, substantial progresses have been made in obtaining starches from non-conventional sources and studying their functional and physicochemical properties [9] where the characteristics of modified starch can be used for industrial applications. Thus, modifying starch is important to provide the following properties such as thickening, gelatinization, adhesiveness or to improve water retention, enhance palatability and to remove or add opacity as well as to modify cooking characteristics, reducing retrogradation, reducing paste's tendency to gelatinize, increasing paste's stability when cooled or frozen, increasing transparency of pastes and gels, improving texture of pastes and gels, improving adhesiveness between different surfaces [10].

Akingbala, et al. reported about a 95-98\% decrease in HCN content after fermentation of cassava during manufacture of fermented cassava. Since food processing usually includes heating, HCN produced is likely to evaporate completely [4]. However, boiling whole cassava root can result in toxicity as the hydrolytic enzymes are denatured by heat without hydrolyzing the HCN. However, cassava and its products are low in protein, deficient in essential amino acids and therefore have poor protein quality [10]. Thus, continuously dependence on fermented cassava without supplementation with protein-rich sources would result in protein deficiency. However, because of the high cost of animal proteins, a protein-rich legume such as soybean with good essential amino acid profile is potentially the most useful protein source for complementing and enhancing the nutritional value of fermented cassava [11].

Supplementation of vegetable proteins to fermented cassava is therefore expected to enhance its protein quantity and quality as well as improve its health promoting benefits $[12,13]$ that is reported to lower cholesterol levels in the blood and its amino acid content which is considered key in its ability to control blood pressure, and this appears to be related to calcium conservation [12], while isoflavone have been reported to play essential roles in preventing certain types of cancers and in reducing the risk of cardiovascular diseases $[14,15]$. This study is undertaken to modify cassava flour using microbial starter culture and fermented product containing PGA to compensate for lack of gluten and leads to changes its physicochemical properties to the search for alternatives to gluten in the manufacture of MCF which is improved in its protein content.

\section{Material and Methods}

\section{Modification Procedure}

Cassava chips $(1.0 \mathrm{~kg})$ were mixed with $2.0 \%(\mathrm{w} / \mathrm{v})$ of enzymatic starter derived from culture of $A$. oryzae and $B$. natto respectively. The mixture was stirred and then incubated at room temperature for $24-48 \mathrm{~h}$, and then dried using oven at $50^{\circ} \mathrm{C}$ for $24-48 \mathrm{~h}$ to reduce moisture content up to lower than $10 \%[16,17]$.

\section{Measurement of HCN Content}

HCN content of cassava flour samples were measured by using alkali titration method [18]. Five $\%(w / v)$ starch slurry was prepared by soaking $10 \mathrm{~g}$ of cassava flour in $200 \mathrm{ml}$ of distilled water for $4 \mathrm{~h}$ in a distillation flask. The solution was then distilled into $20 \mathrm{ml}$ of $0.625 \mathrm{M} \mathrm{NaOH}$ using steam distillation until its volume became $150 \mathrm{ml}$. Distilled water was added and filled up to $250 \mathrm{ml}$. Eight $\mathrm{ml}$ of $5 \% \mathrm{KI}$ was added into $100 \mathrm{ml}$ of solution and titrated using $0.02 \mathrm{~N}$ silver nitrate solution. End point of titration was determined as color of the solution turned to bright yellow.

\section{Proximate Analysis}

Proximate composition of the cassava flour including moisture, ash, fat, and protein contents were determined using Association of Official Analytical Chemists methods [19]. Total carbohydrate content was determined by subtracting the ash, protein, and fat percentages from $100 \%$.

\section{Measurement of Solubility}

Solubility was examined by dissolving 2 gram cassava powder into $40 \mathrm{ml}$ of distilled water, then heated in a water bath at $60^{\circ} \mathrm{C}$ for $30 \mathrm{~min}$. Supernatant and paste were formed, and thus it separated using a centrifuge at $3000 \mathrm{rpm}$ for $20 \mathrm{~min}$. Furthermore approximately $10 \mathrm{ml}$ supernatant was dried using oven and weight of its precipitated was recorded. 


\section{Food Science and Nutrition Technology}

\section{Swelling Power Determination}

Swelling power was examined by dissolving $0.2 \mathrm{~g}$ cassava powder into $20 \mathrm{ml}$ distilled water and heated at $60^{\circ} \mathrm{C}$ for $30 \mathrm{~min}$. Supernatant was separated by centrifugation at $2500 \mathrm{rpm}$ for $15 \mathrm{~min}$. The slurry was heated at $70^{\circ} \mathrm{C}$ for $30 \mathrm{~min}$, cooled to room temperature and furthermore centrifuged at $1200 \mathrm{~g}$ for $15 \mathrm{~min}$. The supernatant was decanted in the centrifuge tube was dried at $50^{\circ} \mathrm{C}$ for $25 \mathrm{~min}$ and weighed prior to adding with distilled water.

\section{Measurement of Viscosity}

Viscosity of cassava flour samples were measured using a viscometer as described by Reddy and Bhotmange [20]. Cassava flour at concentration 1 to $4 \%$ was prepared using distilled water. Each solution was heated for $20 \mathrm{~min}$ and then cooled at room temperature and reading toward their viscosities of each solutions were the recorded.

\section{Observation using Scaning Electron Microscope}

Characteristics of cassava flour granules were observed under Scanning Electron Microscopy (SEM). The respective cassava flour samples i.e. NCF, MCF and FCF were sent to the Faculty of Science and Natural Resources, Universiti Malaysia Sabah for SEM analysis services. Observation by using SEM was conducted to distinguish differences in the structure and morphology of starch granules before and after modification and fortification.

\section{Results and Discussion}

(Table 1) and (Table 2) showed the results of proximate analysis of the respective cassava flour. Statistical analysis showed a significant difference $(p<0.05)$ among of the cassava flour samples. FCF prepared with 10, 20 and 30\% PGA of B. natto showed the highest protein content $(4.74 \% \pm 0.06 \mathrm{c}, 8.67 \% \pm 0.09 \mathrm{~d}$, $12.79 \% \pm 0.06$, respectively) and with 10,20 and $30 \%$ $\mathrm{PGA}$ of $A$. oryzae $\left(5.29 \% \pm 0.01^{\mathrm{b}}, \quad 9.51 \% \pm 0.01^{\mathrm{c}}\right.$, $13.98 \% \pm 0.79 \mathrm{~d}$, respectively) compared with NCF $(1.06 \% \pm 0.11$ and $1.08 \% \pm 0.02)$ and MCF prepared with $B$. natto and $A$. oryzae $\left(0.77 \% \pm 0.07\right.$ a and $0.82 \% \pm 0.00^{\text {a }}$, respectively).

\begin{tabular}{|c|c|c|c|c|c|}
\hline & \multicolumn{5}{|c|}{ Average \pm Standard Deviation (\%) } \\
\hline Analysis & NCF & MCF & FCF-10 & FCF-20 & FCF-30 \\
\hline Moisture & $3.73 \pm 0.12^{\mathrm{a}}$ & $6.08 \pm 0.06^{\mathrm{b}}$ & $7.16 \pm 0.10^{\mathrm{c}}$ & $8.44 \pm 0.05^{\mathrm{d}}$ & $9.81 \pm 0.09^{\mathrm{a}}$ \\
\hline Ash & $1.77 \pm 0.08^{\mathrm{d}}$ & $1.07 \pm 0.12^{\mathrm{a}}$ & $1.30 \pm 0.05^{\mathrm{b}}$ & $1.59 \pm 0.07^{\mathrm{c}}$ & $1.91 \pm 0.17^{\mathrm{e}}$ \\
\hline Crude fat & $0.68 \pm 0.04^{\mathrm{b}}$ & $0.50 \pm 0.15^{\mathrm{a}}$ & $2.35 \pm 0.09^{\mathrm{c}}$ & $4.44 \pm 0.08^{\mathrm{d}}$ & $6.64 \pm 0.11^{\mathrm{e}}$ \\
\hline Crude protein & $1.06 \pm 0.11^{\mathrm{b}}$ & $0.77 \pm 0.07^{\mathrm{a}}$ & $4.74 \pm 0.06^{\mathrm{c}}$ & $8.67 \pm 0.091^{\mathrm{d}}$ & $12.79 \pm 0.06^{\mathrm{e}}$ \\
\hline Crude fiber & $1.58 \pm 0.05^{\mathrm{a}}$ & $1.19 \pm 0.04^{\mathrm{b}}$ & $2.31 \pm 0.11^{\mathrm{c}}$ & $2.68 \pm 0.02^{\mathrm{d}}$ & $3.08 \pm 0.10^{\mathrm{e}}$ \\
\hline Carbohydrate & $91.18 \pm 0.19^{\mathrm{e}}$ & $90.40 \pm 0.05^{\mathrm{d}}$ & $82.15 \pm 0.08^{\mathrm{c}}$ & $74.18 \pm 0.17^{\mathrm{b}}$ & $65.77 \pm 0.14^{\mathrm{a}}$ \\
\hline
\end{tabular}

Table 1: Proximate analysis of NCF compared to MCF prepared with B. natto and FCF prepared with PGA of B. natto.

\begin{tabular}{|c|c|c|c|c|c|}
\hline & \multicolumn{5}{|c|}{ Average \pm Standard Deviation (\%) } \\
\hline \multirow{2}{*}{ Analysis } & \multirow{2}{*}{ NCF } & MCF & FCF-10 & \multirow{2}{*}{ FCF-20 } & \multirow{2}{*}{ FCF-30 } \\
\hline Moisture & $7.13 \pm 0.04^{\mathrm{a}}$ & $8.41 \pm 0.06^{\mathrm{c}}$ & $8.04 \pm 0.01^{\mathrm{b}}$ & $8.06 \pm 0.08^{\mathrm{b}}$ & $8.17 \pm 0.04^{\mathrm{b}}$ \\
\hline Ash & $1.77 \pm 0.03^{\mathrm{cd}}$ & $1.12 \pm 0.02^{\mathrm{a}}$ & $1.43 \pm 0.14^{\mathrm{ab}}$ & $1.55 \pm 0.18^{\mathrm{bc}}$ & $2.00 \pm 0.01^{\mathrm{d}}$ \\
\hline Crude fat & $1.03 \pm 0.40^{\mathrm{a}}$ & $1.29 \pm 0.24^{\mathrm{ab}}$ & $2.54 \pm 0.16^{\mathrm{b}}$ & $5.07 \pm 0.60^{\mathrm{c}}$ & $7.05 \pm 0.12^{\mathrm{d}}$ \\
\hline Crude protein & $1.08 \pm 0.02^{\mathrm{a}}$ & $0.82 \pm 0.00^{\mathrm{a}}$ & $5.29 \pm 0.01^{\mathrm{b}}$ & $9.51 \pm 0.01^{\mathrm{c}}$ & $13.98 \pm 0.79^{\mathrm{d}}$ \\
\hline Crude fiber & $1.25 \pm 0.57^{\mathrm{b}}$ & $0.96 \pm 0.01^{\mathrm{a}}$ & $1.55 \pm 0.01^{\mathrm{c}}$ & $2.96 \pm 0.00^{\mathrm{d}}$ & $3.31 \pm 0.04^{\mathrm{e}}$ \\
\hline Carbohydrate & $87.73 \pm 0.32^{\mathrm{d}}$ & $87.40 \pm 0.33^{\mathrm{d}}$ & $81.16 \pm 0.19^{\mathrm{c}}$ & $72.86 \pm 0.32^{\mathrm{b}}$ & $66.00 \pm 0.19^{\mathrm{a}}$ \\
\hline
\end{tabular}

Table 2: Proximate analysis of NCF compared to MCF prepared with A. oryzae and FCF prepared with PGA of $A$. oryza.

According to Tonukari [21] and Charles et al [22], the protein content of cassava flour was $1-2 \%$ or no more than $4 \%$ [23], and due to low protein content causing flour cassava is only served as a starchy food. Protein content of modified cassava flour was lower than that of the native flour. It might be due to enzymatic activity of Aspergillus oryzae used for incubation of cassava chips. According to Papagianni 2004 [24], A. oryzae potential to produce some other enzymes including protease other than amylase and cellulase. It has catalytic function to 


\section{Food Science and Nutrition Technology}

hydrolyze and degrade peptide bond between amino acids in cassava flour, resulting in lower protein content of modified cassava flour compared with native cassava flour.

Enzymatic modification of cassava flour might encourage a reduction in protein content of cassava flour. According Richana, et al. [19], most of protein contains in cassava flour might be dissolved during modification process. However, fortified cassava flour showed much higher protein content compared to modified and native cassava flour. It is caused by a protein fortification using protein source derived from fermented bean containing PGA. The process of fortification is aimed to increase the protein content in cassava flour while improving quality of its nutrition value. Transglutaminase was added dealing with fortification where this enzyme might play a role on binding of cross-linking a series of protein covalent in cassava flour granules [13].

According to (Tables 3 and 4), statistical analysis showed there was a significant difference $(p<0.05)$ for lipid content of NCF $\left(0.68 \% \pm 0.04^{\mathrm{b}}\right.$ and $\left.1.03 \% \pm 0.40^{\mathrm{a}}\right)$ compared to MCF prepared with B. natto and A. oryzae $\left(0.50 \% \pm 0.15^{\mathrm{a}}\right.$ and $1.29 \% \pm 0.24^{\mathrm{ab}}$, respectively) and FCF prepared with 10,20 and $30 \%$ PGA of B. natto $\left(2.35 \% \pm 0.09 \mathrm{c}, \quad 4.44 \% \pm 0.08^{\mathrm{d}}\right.$ and $6.64 \% \pm 0.11 \mathrm{e}$, respectively) and with 10, 20 and 30\% PGA of A. oryzae $\left(52.54 \% \pm 0.16^{\mathrm{b}}, 5.07 \% \pm 0.60^{\mathrm{c}}, 7.05 \% \pm 0.12^{\mathrm{d}}\right.$, respectively).

\begin{tabular}{|c|c|c|c|c|}
\hline Cassava Flour & Swelling Power & Solubility & Viscosity (Cp) & HCN (mg/kg) \\
\hline NCF & $21.75 \pm 0.12^{\mathrm{e}}$ & $11.57 \pm 0.25^{\mathrm{a}}$ & $14480 \pm 105.83^{\mathrm{e}}$ & $3.71 \pm 0.06^{\mathrm{e}}$ \\
\hline MCF & $18.52 \pm 0.22^{\mathrm{d}}$ & $13.61 \pm 0.10^{\mathrm{b}}$ & $11493 \pm 100.66^{\mathrm{d}}$ & $2.65 \pm 0.05^{\mathrm{d}}$ \\
\hline FCF-10 & $14.34 \pm 0.19^{\mathrm{c}}$ & $16.68 \pm 0.17^{\mathrm{c}}$ & $9140 \pm 280.00^{\mathrm{c}}$ & $1.63 \pm 0.10^{\mathrm{c}}$ \\
\hline FCF-20 & $12.36 \pm 0.13^{\mathrm{b}}$ & $19.33 \pm 0.21^{\mathrm{d}}$ & $8690 \pm 81.85^{\mathrm{b}}$ & $1.22 \pm 0.06^{\mathrm{b}}$ \\
\hline FCF-30 & $9.48 \pm 0.11^{\mathrm{a}}$ & $23.48 \pm 0.20^{\mathrm{e}}$ & $7747 \pm 128.58^{\mathrm{a}}$ & $1.01 \pm 0.06^{\mathrm{a}}$ \\
\hline
\end{tabular}

Table 3: Physicochemical properties of NCF compared to MCF prepared with B. natto and FCF prepared with PGA of $B$. natto.

\begin{tabular}{|c|c|c|c|c|}
\hline Cassava Flour & Swelling Power & Solubility & Viscosity (Cp) & HCN (mg/kg) \\
\hline NCF & $20.62 \pm 0.04^{\mathrm{b}}$ & $11.26 \pm 0.11^{\mathrm{a}}$ & $18960 \pm 678.82^{\mathrm{c}}$ & $1.72 \pm 0.01^{\mathrm{d}}$ \\
\hline MCF & $19.04 \pm 0.28^{\mathrm{b}}$ & $13.55 \pm 0.13^{\mathrm{b}}$ & $14185 \pm 417.19^{\mathrm{b}}$ & $0.65 \pm 0.00^{\mathrm{c}}$ \\
\hline FCF-10 & $11.59 \pm 0.09^{\mathrm{a}}$ & $16.42 \pm 0.30^{\mathrm{c}}$ & $8250 \pm 155.56^{\mathrm{a}}$ & $0.43 \pm 0.00^{\mathrm{b}}$ \\
\hline FCF-20 & $11.16 \pm 0.28^{\mathrm{a}}$ & $19.23 \pm 0.47^{\mathrm{d}}$ & $7840 \pm 452.55^{\mathrm{a}}$ & $0.22 \pm 0.00^{\mathrm{a}}$ \\
\hline FCF-30 & $11.02 \pm 0.20^{\mathrm{a}}$ & $23.09 \pm 0.18^{\mathrm{e}}$ & $6660 \pm 197.99^{\mathrm{a}}$ & $0.22 \pm 0.00^{\mathrm{a}}$ \\
\hline
\end{tabular}

Table 4: Physicochemical properties of NCF compared to MCF prepared with A. oryzae and FCF prepared with PGA of $A$. oryzae.

According to Charles, et al. [22], lipid content of native cassava flour is approximately $0.1 \%$ to $0.4 \%$ based on dry weight of raw material. According to Papagianni [24], A. oryzae potential to produce some other enzymes including lipase other than amylase and cellulase since crude enzyme was used as starter culture that has catalytic function to hydrolyze and degrade lipid content of cassava flour to be a simpler molecule including fatty acid and glycerol. As a hydrolysis product it was furthermore dissolved into incubation media and drained with enzyme solution before process of drying.

Statistical analysis showed there was a significant difference $(\mathrm{p}<0.05)$ for cyanide $(\mathrm{HCN})$ content among of cassava flour samples. NCF showed the highest HCN content $\quad\left(3.71 \mathrm{mg} / \mathrm{kg} \pm 0.06^{\mathrm{e}}\right.$ and $\left.1.72 \mathrm{mg} / \mathrm{kg} \pm 0.01 \mathrm{~d}\right)$ compared to MCF prepared with B. natto and A. oryzae $\left(2.65 \mathrm{mg} / \mathrm{kg} \pm 0.05^{\mathrm{d}}\right.$ and $0.65 \mathrm{mg} / \mathrm{kg} \pm 0.00^{\mathrm{c}}$, respectively) and FCF prepared with 10, 20 and 30\% PGA of B. natto showed the lowest HCN content $\left(1.63 \mathrm{mg} / \mathrm{kg} \pm 0.10^{c}, 1.22\right.$ $\mathrm{mg} / \mathrm{kg} \pm 0.06^{\mathrm{b}}, 1.01 \mathrm{mg} / \mathrm{kg} \pm 0.06^{\mathrm{a}}$, respectively) and with 10,20 and $30 \%$ PGA of A. oryzae $\left(0.43 \mathrm{mg} / \mathrm{kg} \pm 0.01^{\mathrm{d}}\right.$, $0.22 \mathrm{mg} / \mathrm{kg} \pm 0.00^{a}, 0.22 \mathrm{mg} / \mathrm{kg} \pm 0.00^{\mathrm{a}}$, respectively) Table 3 and 4 .

According to standard of WHO these three cassava flour were actually safe to be consumed, since the HCN content did not exceed than $10 \mathrm{ppm}$ as determined by using HPLC [25,26]. Akindahunsi, et al. [27] reported that reducing amount of $\mathrm{HCN}$ in cassava flour to be safety level was due to linamarin and lotaustralin in cassava had been sequentially destroyed and degraded to be free cyanide 


\section{Food Science and Nutrition Technology}

during flour producing process including enzymatic process. Thus, the process involved in the production of cassava flour may be as detoxification process to make it safe for consumption and possibly for manufacturing of food products $[28,29]$.

The value of swelling power, solubility, and viscosity of the cassava flour samples have been summarized in Table 3 and 4 which shown there was significant difference ( $p>0.05$ ) in the swelling power among of these cassava flour. The swelling power of MCF modified with starter culture of $B$. natto $\left(18.52 \% \pm 0.22^{\mathrm{d}}\right)$ was slightly decrease compared to swelling power of NCF $\left(21.75 \% \pm 0.12^{\mathrm{e}}\right)$ and significantly decreased compared to FCF prepared with 10,20 and $30 \%$ PGA of $B$. natto $\left(14.34 \% \pm 0.19^{c}\right.$, $12.36 \% \pm 0.13^{\mathrm{b}}$ and $9.48 \% \pm 0.11^{\mathrm{a}}$, respectively). The statistical analysis showed there was no significant $(\mathrm{p}<0.05)$ difference in the swelling power between NFC $\left(20.62 \% \pm 0.04^{\mathrm{b}}\right)$ and MCF modified with starter culture of A. oryzae $\left(19.04 \% \pm 0.28^{\mathrm{b}}\right)$ and there was only slightly significant differences between NCF compared to FCF prepared with 10, 20 and $30 \%$ PGA of $A$. oryzae $(11.59 \% \pm$ $0.09^{\mathrm{a}}, 11.16 \% \pm 0.28^{\mathrm{a}}$ and $11.02 \% \pm 0.20^{\mathrm{a}}$, respectively).

Swelling properties is a capacity of flour to bind water molecules through hydrogen bonding [21]. Swelling of cassava starch granules proves that there was interaction among of the starch chains with amorphous and crystalline regions [30]. The MCF showed the highest swelling power since there was a rejection among of negative charged of phosphate groups on amylopectin chains. It would weaken hydrogen bonds inside the chain led to cause hydration and high swelling power [31,32].

As shown in Table 3 and 4, statistical analysis showed there was a significant difference $(\mathrm{p}<0.05)$ for solubility among of cassava flour samples. NCF showed the lowest solubility $\left(11.57 \% \pm 0.25^{\mathrm{a}}\right.$ and $\left.11.26 \% \pm 0.11^{\mathrm{a}}\right)$ compared to MCF prepared with B. natto and A. oryzae $\left(13.61 \% \pm 0.10^{\mathrm{b}}\right.$ and $13.55 \% \pm 0.13^{\mathrm{b}}$, respectively) and FCF prepared with 10, 20 and 30\% PGA of B. natto showed the highest solubility $\quad\left(16.68 \% \pm 0.17^{\mathrm{c}}, \quad 19.33 \% \pm 0.21^{\mathrm{d}}\right.$ and $23.48 \% \pm 0.20$, respectively), as well as prepared with 10 , 20 and $30 \%$ PGA of $A$. oryzae $\left(16.42 \% \pm 0.30^{c}, 19.23 \% \pm\right.$ $0.47^{\mathrm{d}}$ and $23.09 \% \pm 0.18^{\mathrm{e}}$, respectively).

Both of MCF and FCF showed higher solubility due to hydrolysis by enzyme amylase on starch granules containing internal bond of $\alpha-1$, 4-glycosidic linkages to break it down into glucose [33]. The solubility properties are a capacity of starch granule to bind water by formation of hydrogen bonds with water molecules [34].
The hydrolysis of starch granules have increased motility of granules in which breaking of granules bonds will increase the spread of the granules in water molecules when it is heated. More water molecules would penetrate and form hydrogen bonds with the starch granules and thus the solubility of MCF and FCF was increased [35]. In addition, amount of amylose contained in cassava flour was a major factor that affected the swelling power of starch granules [35]. Amylose was an obstacle for granules to swell and served to maintain integrity of swelling [31]. Cassava flour that has more amylose content has a lower swelling power [33].

As shown in Table 3 and 4, there was significant difference $(p>0.05)$ in viscosity of MCF with starter culture of B. natto and A. oryzae $\left(11493 \mathrm{cp} \pm 100.66^{\mathrm{d}}\right.$ and $14185 \mathrm{cp} \pm 417.19^{\mathrm{b}}$, respectively), compared to viscosity of NCF (14480cp $\pm 105.83^{\mathrm{e}}$ and 18960cp \pm 678.82 ${ }^{\mathrm{c}}$ ) and significantly decreased compared to FCF prepared with 10,20 and $30 \%$ PGA of B. natto $\left(9140 \mathrm{cp} \pm 280.00^{\mathrm{c}}\right.$, $8690 \mathrm{cp} \pm 81.85^{\mathrm{b}}$ and $7747 \mathrm{cp} \pm 128.58^{\mathrm{a}}$, respectively), however, there was only slightly significant different compared to FCF prepared with 10, 20 and 30\% PGA of $A$. oryzae $\quad\left(8250 \mathrm{cp} \pm 155.56^{\mathrm{a}}, \quad 7840 \mathrm{cp} \pm 452.55^{\mathrm{a}}\right.$ and $6660 \mathrm{cp} \pm 197.99^{\mathrm{a}}$, respectively).

Overall, NCF exhibited the highest viscosity compared to MCF and FCF. Viscosity properties may be defined as resistance of a substance to flow and it will increase when temperature decreases and vice versa, the resistance of flow will decrease as the temperature rises. The viscosity of flour will increase or decrease depending on type of modification being performed [36]. The difference among of viscosity of the three cassava flour may be depended on degree of hydrolysis towards granules of starch, total content of starch and fiber content that is contained in cassava flour [20]. The higher process on enzymatic hydrolysis towards starch granules will contribute to degrading of granules and reduction in amount of available granules in cassava flour and reducing amount of starch will directly lead to decreasing in the viscosity of flour, and therefore MCF and FCF had a lower viscosity.

Observing of structure of the cassava starch granules using SEM showed that cassava flour granules revealed a different morphology after modification as shown in Figure1 and 2. According to Putri, et al. [30] diameter of cassava starch granules were varied in the range of 3$10 \mu \mathrm{m}$ and exhibited irregular shape with longitude and ellipsoid truncated shape with one side containing a cone hole where the hole was very deep for some starch granules. Hydrolysis that occurred toward cassava flour 


\section{Food Science and Nutrition Technology}

granules could be categorized based on intensity and the way in which granules eroded and diminished [16]. The degree of hydrolysis that occurred over modified starch granules could be identified by the shape and size of each granule. It showed that modification process indicated different morphology of starch granules compared unfermented starch granules.

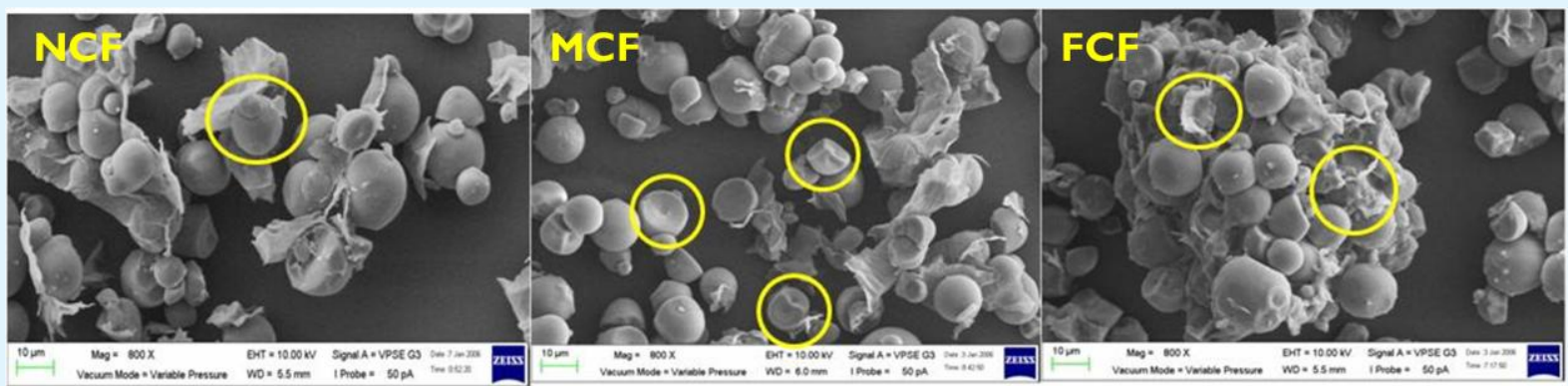

Figure 1: SEM observation on starch granules of NCF (A, left) compared to MCF (B, middle) prepared with B. natto and FCF prepared with PGA of B. natto (C, right).

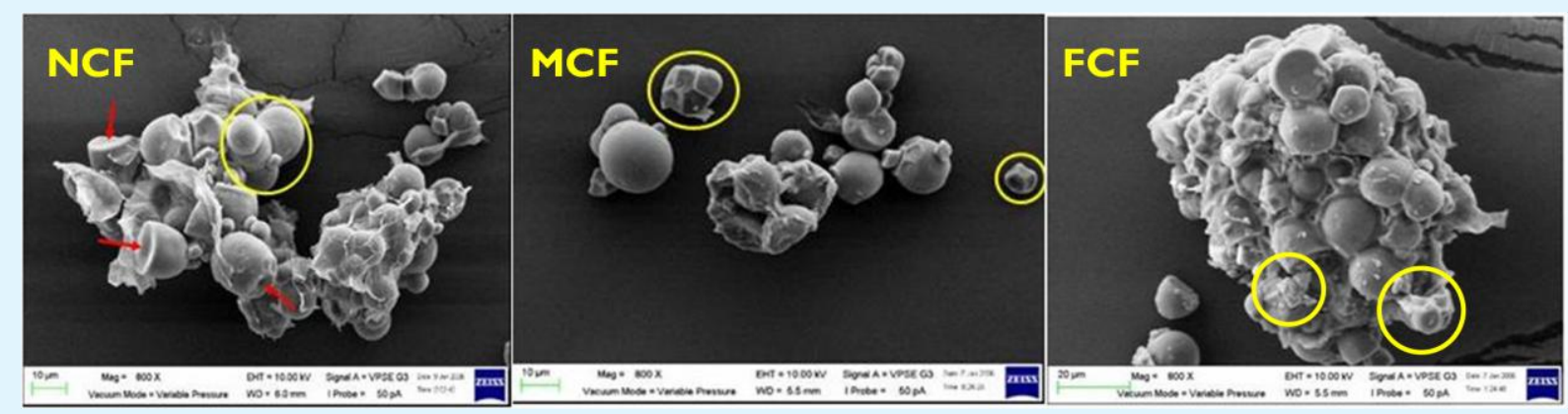

Figure 2: SEM observation on starch granules of NCF (A, left) compared to MCF (B, middle) prepared with A. oryzae and FCF prepared with PGA of $A$ oryzae (C, right).

From the SEM micrographs, the process of corrosion and enzymatic hydrolysis on cassava starch granules occurred mainly on surface of starch granules as shown in Figure $1 \mathrm{~B}$ and $2 \mathrm{~B}$ as well as $1 \mathrm{C}$ and $2 \mathrm{C}$. Qualitatively, rough surface and eroded starch granules could be observed in Figure 1B and 2B as well as $1 \mathrm{C}$ and $2 \mathrm{C}$ of that MCF was prepared with starter culture of $B$. natto and $A$. oryzae, respectively and FCF was fortified with PGA of $B$. natto and $A$. oryzae, respectively, compared to Figure $1 \mathrm{~A}$ and $2 \mathrm{~A}$ of the respective NCF. Figure $1 \mathrm{~A}$ and $2 \mathrm{~A}$ showed smooth surface of starch granule with irregular sections while Figure $1 \mathrm{~B}$ and $2 \mathrm{~B}$ as well as $1 \mathrm{C}$ and $2 \mathrm{C}$ of the respective MCF and FCF exhibited that some of starch granules had been broken with rough and eroded surface. Refer to the Figure $1 \mathrm{~B}$ and $2 \mathrm{~B}$ as well as $1 \mathrm{C}$ and $2 \mathrm{C}$, size of some granules had become smaller and the amount of the granules had become increasingly decreased. According to Putri, et al. [30], the granule molecules that were reside in amorphous region had been depolymerized by enzymatic hydrolysis process. According to Shariffa, et al. [16], enzymatic hydrolysis by amylase had taken place in which the amylase was able to cause change and degrade exterior surface of the granules by exo and endocorrosion occurence. Through small pores of the granules subjected to enzyme penetration process into the starch granules to hydrolyze inside part of starch granules of modified and fortified cassava flour [37-43].

\section{Aknowledgement}

This work was financially supported by Fundamental Research Grant Scheme Phase 1/2014, under the Ministry of Education Malaysia in cooperation with Universiti Malaysia Sabah.

\section{References}

1. Lee SJ, Yan W, Ahn JK, Chung IM (2003) Effects of year, site, genotype and their interactions on various soybean isoflavones. Field Crops Res 81(2-3): 181192. 


\section{Food Science and Nutrition Technology}

2. Hahn SK, Keyser J (1985) Cassava. A basic food of Africa. Outlook on Agric 14: 95-100.

3. Cooke RD, Coursey DG (1981) Cassava: A major cyanide-containing food crop, in Cyanide in Biology, edited by Vennesland et al. Academic Press, New York, NY, USA, pp: 93-114.

4. Akingbala JO, Oguntimehin GB, Abass AB (1991) Effect of Processing Method on Quality and Acceptability of "Fufu" from Low Cyanide Cassava. J Sci Food Agri 57(1): 151-154.

5. Demiate IM, Cereda MP (2000) Some physicochemical characteristics of modified cassava starches presenting baking property. Energy Agr 15(3): 36-46.

6. Hirsch JB, Kokini JL (2002) Understanding the mechanism of cross linking agents (POCl3, STMP, and EPI) through swelling behavior and pasting properties of cross linked waxy maize starches. Cereal Chem 79: 102-107.

7. Mirmoghtadaei L, Kadivar M, Shahedi M (2009) Effect of cross linking and acetylation on oat starch properties. Food Chem 116: 709-713.

8. Miyazaki M, Hung PV, Maeda T, Morita N (2006) Recent advances in application of modified starches for bread making. Trend of Food Sci Technol 17: 591599.

9. Hoover R (2001) Composition, molecular structure, and physicochemical properties of tuber and root starches: A Review. Carbohyd. Polym 45(3): 253-267.

10. Oboh G, Akindahunsi AA (2003) Biochemical changes in cassava products subjected to Saccharomyces cerevisiae solid media fermentation. Food Chem 82: 599-602.

11. Redondo-Cuenca A, Villanueva-Suarez MJ, RodrIguezSevilla MD, Mateos-Aparicio I (2006) Chemical composition and dietary fibre of yellow and green commercial soybeans (Glycine max). Food Chem 101: 1216-1222.

12. Dadson RB, Noureldin NA (2001) Soybeans in Egypt: Research, production Akingbala, economics, nutrition and health. Bethesda: University Press of Maryland: 143-169.
13. Marco C, Rosell CM (2008) Functional and Rheological Properties of Protein Enriched Gluten Free Composite Flour. J Food Eng 88(1): 94-103.

14. Ren H, Liu H, Endo H, Takagi Y, Hayashi T (2006) Antimutagenic and antioxidative activities found in Chinese traditional soybean fermented products furu. Food Chem 95: 71-76.

15. Rostagno MA, Palma M, Barroso CG (2005) Shortterm stability of soy isoflavones extracts: sample conservation aspects. Food Chem 93: 557-564.

16. Shariffa Y, Karima AA, Fazilaha A, Zaidulb I (2009) Enzymatic hydrolysis of granular native and mildly heat-treated tapioca and sweet potato starches at sub-gelatinization temperature. Food Hydrocol 23(2): 434-440.

17. Richana N, Budiyanto A, Mulyawati I (2010) Lactic acid bacteria for fermentation of the modified corn flour production. Proceed. the 3rd Intl. Conf. Indonesian Soc. Lactic Acid Bacteria: Better Life with Lactic Acid Bacteria: Exploring Novel Functions of Lactic Acid Bacteria, Yogyakarta, Indonesia.

18. Betiku E, Alade OS (2011) Investigation of Effects of Different Cassava Cultivars with Respect to Hydrogen Cyanide Content on Their Starch Hydrolysis. Intl J Biol Chem Sci 5(6): 2362-2370.

19. AOAC (2005) Official Methods of Analysis, 19th Edition (Association of Analytical Chemists, Washington DC 5(7):1-167.

20. Reddy DK, Bhotmange MG (2014) Viscosity of starch: a comparative study of indian rice (Oryza Sativa L.) varieties. Intl Rev.Appl Eng Res 4(5): 397-402.

21. Tonukari NJ (2004) Cassava and the future of starch. J Biotechnol 7(1): 5-8.

22. Charles AL, Sriroth K, Huang TC (2005) Proximate Composition, Mineral Contents, Hydrogen Cyanide and Phytic Acid of Five Cassava Genotypes. Food Chem 92(4): 615-620.

23. Beninca C, Colman TAD, Lacerda LG, Filho MASC, Bannach G, Schnitzler E (2013) The Thermal, Rheological and Structural Properties of Cassava Starch Granules Modified with Hydrochloric Acid at Different Temperatures. Thermochimica Acta 552: 65-69. 


\section{Food Science and Nutrition Technology}

24. Papagiani M (2004) Fungal morphology and metabolite production in submerged mycelial processes. Biotech. Adv 22(3): 189-259.

25. Burns AE, Bardbury JH, Cavagnaro TR, Gleadow RM (2012) Total Cyanide Content of Cassava Food Products in Australia. J Food Compost Anal 25(1): 7982.

26. Cardoso AP, Mirione E, Ernesto M, Massaza F, Cliff J, et al. (2005) Processing of cassava roots to remove cyanogens. J Food Compost Anal 18: 451-460.

27. Akindahunsi AA, Oboh G, Oshodi AA (1999) Effect of Fermenting Cassava with Rhizopus oryzae on the Chemical Composition of Its Flour and Gari Products. Rivista Italiana delle Sostanze Grasse 76(10): 437439.

28. Okaka JC, Okaka ANC (2001) Foods: Composition, Spoilage, Shelf-life Extension. OcJanco Academic Publishers, Enugu-Nigeria pp: 1-2.

29. Udoudoh PJ (2011) Post-harvest storage and spoilage of cassava tubers (Manihot spp) in Ikot Ekpene, Akwa Ibom State, Nigeria. J Environ Issues and Agriulture in Developing Countries 3(3): 34-35.

30. Putri WDR, Haryadi DW, Marseno, Cahyanto MN (2011) Effect of biodegradation by lactic acid bacteria on physical properties of cassava starch. Intl Food Res J 18(3): 1149-1154.

31. Ahmed J, Tiwari BK, Imam AH, Rao MA (2012) StarchBased Polymeric Materials and Nanocomposites. USA: Taylor and Francis Group.

32. Yuan Y, Zhang LM, Dai YJ, Yu JG (2007) Physicochemical properties of starch obtained from Dioscorea nipponica Makino comparison with other tuber starches. J Food Eng 82: 436-442.

33. Afiukwa CA, Ibiam UA, Edeogu CO, Nweke FN, Chukwu UE (2009) Determination of amylase activity of crude extract from partially germinated mango seeds (Mangifera oraphila). African J Biotech 8(14): 3294-3296.
34. Gunorubon AJ, Kekpugile DK (2012) Modification of cassava starch for industrial uses. Intl J Eng Technol 2(6): 914-919.

35. Udoro EO, Kehinde AT, Olasunkanmi SG, Charles TA (2014) Studies on the physicochemical, functional and sensory properties of gari processed from dried chips. J Food Process Technol 5(1): 1-8.

36. Agboola SO, Akingbala JO, Oguntimehin GB (1991) Production of low substituted cassava starch acelates and citrates. Starches 4(1): 13-15.

37. Murillo CEC, Wang YJ, Perez LAB (2008) Morphological, structural and physicochemical characteristics of oxidized barley and corn starch. Starch 60(11): 634-645.

38. Balagopalan C, Padmaja G, Nanda SK, Moorthy SN (1988) Cassava Utilization in Food, Feed, and Industry. USA : CRC Press, Boca Raton 205.

39. Montagnac JA, Davis CR, Tanumihardjo SA (2009) Nutritional Value of Cassava for Use as a Staple Food and Recent Advances For Improvement. Compr Rev Food Sci Food Safety 8(3): 181-194.

40. Rathore SSS (2009) Decision making in dry-grind ethanol industry using near-infrared spectroscopy. Ann Arbor: ProQuest LLC.

41. Sulistyo J, Nakahara K (2014) Physicochemical properties of modified cassava starch prepared by application of mixed microbial starter. IJRAFS 2(7): 18.

42. Sun J, Zhao R, Zeng J, Li X (2010) Characterization of Dextrins with different dextrose equivalents. Molecules 15: 5162-5173.

43. Takizawa FF, da Silva GO, Konkel FE, Demiate IM (2004) Characterization of tropical starches modified with potassium permanganate and lactic acid. Brazilian Arch Biol Technol 47: 921-931. 